\title{
Pengembangan Bahan Ajar Modul Elektronik Interaktif Pada Mata Kuliah Inovasi Pendidikan Program Studi Teknologi Pendidikan Universitas Baturaja.
}

\author{
Johan Eka Wijaya ${ }^{1}$, Ade Vidianti ${ }^{2}$ \\ ${ }^{1}$ Universitas Baturaja \\ Email: johanekawijaya@gmail.com \\ ${ }^{2}$ Universitas Baturaja \\ Email: fiad_07@yahoo.co.id
}

\section{Jounal info \\ Jurnal Pendidikan Glasser \\ p-ISSN : 2579-5082 \\ e-ISSN : 2598-2818 \\ DOI :}

10.32529/glasser.v\%vi\%i.334

Volume : 3

Nomor : 2

Month : 2019

Issue : oktober

\begin{abstract}
.
Tujuan dari penelitian ini adalah mengembangkan bahan ajar modul elektronik interaktif pada mata kuliah inovasi pendidikan. Model pengembangan yang digunakan dalam penelitian ini yaitu model penelitian dan pengembangan (Research \& Development). Pendekatan yang dilakukan adalah mix methods research yaitu menggabungkan metode kualitatif dan kuantitatif. Model pengembangan yang diterapkan adalah yang dikemukakan oleh Rowntree yang terdiri dari tiga tahapan yaitu 1) Perencanaan 2) Persiapan penulisan 3). Penulisan dan penyuntingan yang dalam hal ini merupakan tahan pengembangan produk dengan menggunakan software Flip PDF Profesional dan menghasilkan modul elektronik interaktif. Namun, model Rowntree ini tidak utuh pada bagian evaluasi produknya oleh karena itu model ini akan peneliti kolaborasikan dengan model evaluasi Tessmer sehingga ketidak utuhan model Rowntree akan tertutupi oleh kelebihan model evaluasi formatif Tessmer. Model Tessmer memiliki lima tahapan evaluasi yaitu self evaluation (evaluasi diri sendiri); expert reviews (evaluasi ahli); one-to-one (evaluasi satu-satu); small group (evaluasi kelompok kecil); dan field test (evaluasi lapangan). Lebih sering suatu produk di evaluasi maka hasilnya akan lebih menarik, dengan terkolaborasinya kedua model ini, maka diharapkan dapat menghasilkan modul yang valid, praktis, dan efektif.
\end{abstract}

Keywords:

Bahan Ajar, Modul Elektronik Interaktif, Inovasi Pendidikan

\section{A. PENDAHULUAN}

Inovasi Pendidikan adalah salah satu Mata kuliah Keterampilan Berkarya (MKB) yang ada di Program Studi Teknologi Pendidikan, Fakultas Keguruan dan Ilmu Pendidikan, Universitas Baturaja. Tujuan pembelajaran dari mata kuliah ini adalah mahasiswa nantinya mampu memahami konsep dasar inovasi pendidikan, karakteristik inovasi pendidikan, proses inovasi pendidikan, hambatan difusi inovasi, startegi inovasi pendidikan, inovasi kurikulum, inovasi dalam pembelajaran, inovasi pembelajaran melalui teknologi informasi (internet) dan cara melakukan inovasi berdasarkan permasalahan yang ada serta mampu mengaplikasikannya sesuai dengan 
kebutuhan masyarakat. Intinya setelah mengikuti mata kuliah ini diharapkan mahasiswa mampu menciptakan suatu inovasi di dalam dunia pendidikan. Oleh sebab itu, mahasiswa dituntut untuk lebih aktif dalam belajar, lebih mandiri, dan lebih kreatif mengeluarkan ide untuk dapat menciptakan suatu inovasi di dalam dunia pendidikan.

Proses pembelajarannya berlangsung dalam bentuk pengarahan diri sendiri untuk memecahkan masalah (Suprijanto, 2008). Agar mahasiswa dapat belajar secara mandiri, maka perlu diberikan sarana untuk membantu belajar. Sarana tersebut dapat berbentuk bahan ajar. Bahan ajar merupakan bahan-bahan atau materi perkuliahan yang disusun secara sistematis, yang digunakan dosen dan mahasiswa dalam proses pembelajaran (Pannen,2001). Bahan ajar dapat berbentuk cetak dan non cetak.

Salah satu bagian dari bahan ajar adalah modul. Modul merupakan media atau sarana pembelajaran yang berisi materi pembelajaran, metode, petunjuk kegiatan pembelajaran, latihan dan cara mengevaluasi yang dirancang secara sistematis dan menarik untuk mencapai kompetensi yang diharapkan dan digunakan secara mandiri (Hamdani, 2011). Tujuan utama dari bahan ajar berbentuk modul adalah pembaca bisa menyerap materi atau bahan ajar secara mandiri (Daryanto, 2013). Terdapat beberapa karakteristik dari modul diantaranya: 1) Self Instructional; 2) Self Contained; 3) Stand Alone (berdiri sendiri); 4) Adaptive; dan 5) User Friendly. (Depdiknas, 2008). Sebuah modul bisa dikatakan baik dan menarik apabila memiliki karakteristik tersebut.

Proses pembelajaran yang berlangsung saat ini pada mata kuliah inovasi pendidikan di program studi Teknologi Pendidikan Universitas Baturaja masih menggunakan modul cetak. Hal ini masih dinilai kurang efektif dan efisien. Berkembangnya ilmu, teknologi dan informasi membawa perubahan dan paradigma baru pada learning material dan learning method (Darmawan : 2012). Pemanfaatan teknologi informasi dalam pembelajaran akan menciptakan proses pembelajaran yang menarik dan bermakna bagi siswa (Makki. B, 2012). Produk dari teknologi dan infomasi telah memberikan alternatif bahan ajar yang dapat digunakan dan diakses peserta didik dalam bentuk digital seperti e-modul.

Bahan ajar e-modul interaktif merupakan salah satu bahan ajar yang proses penerbitannya dalam bentuk digital terdiri dari teks, gambar atau gabungan keduanya. E-modul adalah modul elektronik yang merupakan bahan ajar yang disajikan secara sistematis sehingga penggunaannya dapat belajar dengan atau tanpa seorang fasilitator atau guru/dosen (Prastowo: 2011). 
Berdasarkan pemaparan diatas maka perlu dilakukan pengembangan bahan ajar modul elektronik interaktif pada mata kuliah inovasi pendidikan program studi Teknologi Pendidikan Universitas Baturaja. Modul elektronik interaktif yang akan dikembangkan juga didukung dengan unsur multimedia. Berdasarkan hasil beberapa penelitian yang menjelaskan responden siswa yang positif terhadap E-Module karena E-Modul dianggap lebih menarik, ada elemen multimedia yang akan membuat pembelajaran lebih menarik (Lim, J., Yunos, J. M., \& Spahat, G. (2005). Hal ini bertujuan agar mahasiswa tertarik dan lebih aktif, mandiri, dan kreatif mengeluarkan ide dalam belajar. Dengan hasil penelitian ini pula maka menciptakan suatu inovasi di dalam pengembangan bahan ajar dari bahan ajar cetak menjadi modul elektronik interaktif khusunya pada mata kuliah inovasi pendidikan.

\section{B. METODE PENELITIAN}

Penelitian ini yaitu menggunakan metode pengembangan (Research \& Development) (Sugiono:2010).Model pengembangan yang digunakan adalah model yang dikemukan oleh Rowntree yaitu tahap perencanaan, tahap pengembangan dan tahap evaluasi (Prawiradilaga : 2009). Namun, model Rowntree ini tidak utuh pada bagian evaluasi produknya, oleh karena itu model ini akan dikolaborasikan dengan model evaluasi Tessmer sehingga ketidakutuhan model Rowntree akan tertutupi oleh kelebihan model evaluasi formatif Tessmer
(Tessmer:1998). Alur penelitian dapat dilihat pada bagan berikut :

1. Tahap Perencanaan yang terdiri dari beberapa kegiatan yaitu:

a) Analisis kebutuhan

b) Merumuskan tujuan umum dan tujuan khusus;

c) Menyusun garis besar isi

d) Menetukan analisis konsep

e) Menetukan media dan peralatan.

2. Tahap pengembangan terdiri dari:

a) Menyusun draf/storyboard

b) Memproduksi produk

c) Proses penginputan materi

d) Finishing produk.

3. Tahap Evaluasi terdiri dari lima tahap evaluasinya yaitu :

a) self evaluation (evaluasi diri sendiri);

b) expert reviews (evaluasi ahli)

c) one-to-one (evaluasi satu-satu)

d) small group (evaluasi kelompok kecil)

e) field test (evaluasi lapangan)

Penjabaran dari tahap evaluasi adalah sebagai berikut :

a) Evaluasi diri sendiri (self evaluation). Pada tahap ini peneliti mengevaluasi sendiri draf modul elektronik interaktif yang telah dikembangkan sebelum divalidasi oleh tim ahli dan uji coba produk. Peneliti juga meminta saran ke pada teman sejawat yang meliputi: isi, bahasa, desain modul elektronik interaktif, dan lain-lain yang berhubungan dengan penyempurnaan modul elektronik interaktif. Kemudian merevisi draf sesuai 
dengan saran yang didapat dan hasil revisi disebut draf 1.

b) Evaluasi ahli (expert reviews)

Draf modul elektronik interaktif ke 1 diujikan kepada 3 orang ahli yakni ahli substansi isi/content modul elektronik interaktif, ahli bahasa dan ahli desain intruksional. Validasi ahli dilakukan untuk menguji tingkat kevalidan modul elektronik interaktif yang dikembangkan. Validasi ahli dilakukan dengan cara meminta saran dan komentar dari para ahli berkenaan dengan indikator yang akan dinilai.

c) Evaluasi satu-satu (one-to-one)

Evaluasi satu-satu dilakukan bersamaan dengan evaluasi ahli. Evaluasi ini dilakukan untuk mengukur tingkat praktikalitas dari modul elektronik interaktif yang dikembangkan. Pada saat pengujian dipilih 3 orang mahasiswa yang mempunyai tingkat kemampuan yang berbeda (rendah, sedang, dan tinggi).

d) Evaluasi kelompok kecil (small group)

Sama halnya dengan evaluasi satu satu. Evaluasi kelompok kecil juga dilakukan untuk mengukur tingkat praktikalitas dari modul elektronik interaktif yang dikembangkan namun waktu pelaksanaannya dilakukan setelah evaluasi satu-satu. Pada tahap ini draf modul elektronik interaktif ke 2 diujicobakan ke pada sekelompok kecil mahasiswa sebelum diujicobakan ke kelas sebenarnya. Evaluasi ini dilakukan dengan memilih 10-20 orang mahasiswa yang berbeda kemampuan. e) Evaluasi lapangan (field test)

Evaluasi lapangan menggunakan draf ke 3. Dilakukan di kelas yang mengikuti mata kuliah inovasi pendidikan. Evaluasi lapangan ini merupakan tahap akhir dari evaluasi modul elektronik interaktif untuk mengetahui dampak potensial yang ditimbulkan dari modul elektronik interaktif yang dikembangkan.

Persentase dari tiap-tiap instrumen dengan rumus yang mengacu pada pendapat Sudijono (2011) sebagai berikut :

$p=\frac{\mathbf{f}}{\mathrm{N}} \boldsymbol{x} 100 \%$

Keteranga

$\mathrm{p}$ : angka persentase

f : frekuensi yang sedang dicari

persentasenya

$\mathrm{N}$ : Number of Cases (jumlah frekuensi)

Kemudian hasilnya disesuaikan dengan kriteria yang di sampaikan Arikunto (2010) sebagai berikut :

\begin{tabular}{|c|c|l|l|}
\hline \multirow{2}{*}{$\begin{array}{c}\text { Interval } \\
\text { Persentase }\end{array}$} & $\begin{array}{c}\text { Nilai ubahan skala } \\
\text { empat }\end{array}$ & \multirow{2}{*}{ Keterangan } \\
\cline { 2 - 3 } & $\mathbf{0}-\mathbf{4}$ & D - A & \\
\hline $81-100$ & 5 & A & Sangat Baik \\
\hline $61-80$ & 4 & B & Baik \\
\hline $41-60$ & 3 & C & Cukup \\
\hline $21-40$ & 2 & D & Kurang Baik \\
\hline$<20$ & 1 & E & Buruk \\
\hline
\end{tabular}

\section{HASIL DAN PEMBAHASAN}

Pada tahap ini dikembangkannya bahan ajar modul elektronik interaktif yang selanjutnya akan di uji kevalidannya oleh beberapa ahli diantaranya ahli media, ahli materi, ahli desain dan ahli bahasa. Serta beberapa 
mahasiswa sebagai pengguna bahan ajar modul elektronik interaktif.

Tahap selanjutnya dilakukan pengolahan data yang diperoleh dari para validator dan subyek uji coba. Dengan mengacu pada teknik analisis data yang telah ditentukan. Dari tahapan itu maka diperoleh hasil analisis dari masing-masing validator dan subyek uji coba. Berdasarkan hasil uji validasi dari ahli media, didapatkan persentase nilai adalah $77 \%$ dengan predikat baik. Dan persentase hasil uji validasi ahli materi didapat persentase secara keseluruhan dengan hasil nilai $78 \%$ dengan predikat baik. Ahli desan $82 \%$ dengan predikat sangat baik dan ahli bahasa $81 \%$ dengan predikat sangat baik. Sehingga dari sisi media dan materi yang dihasilkan dikategorikan BAIK atau valid. Berdasarkan komentar dan saran yang diberikan, perlu dilakukan perbaikan pada media yaitu warna dan teks yang digunakan harus lebih disesuaikan dengan materi yang disajikan serta penambahkan video pada materi yang dianggap perlu untuk digambarkan secara nyata kepada mahasiswa.

Dari analisis data uji coba skala perorangan dengan objek penelitian sebagai responden 3 orang mahasiswa dengan persentase rata-rata keseluruhan aspek Pembelajaran yang ada pada modul elektronik interaktif adalah $93 \%$ dengan predikat sangat baik. Selanjutnya dilakukan tahap III yaitu melakukan uji produk skala kecil dengan responden 10 orang mahasiswa dengan persentase rata-rata keseluruhan aspek pembelajaran pada bahan ajar modul elektronik interaktif adalah $88 \%$ dengan predikat sangat baik. Selanjutnya dilakukan tahap IV yaitu melakukan uji produk skala besar dengan responden 20 mahasiswa dengan persentase rata-rata adalah $90 \%$ dengan predikat sangat baik. Secara keseluruan dapat disimpulkan bahwa produk memiliki tingkat kelayakan yang baik sekali karena mampu mengatasi dan mempermudah dosen dan mahasiswa dalam kegiatan pembelajaran pada mata kuliah Inovasi Pendidikan.

\section{PENUTUP}

Produk yang dihasilkan yaitu Bahan ajar modul elektronik interaktif yang berisi materi pembelajaran mata kuliah Inovasi. Bahan ajar modul elektronik interaktif dikembangkan dilengkapi dengan efek multimedia seperti teks, gambar, suara, dan video. Dari validasi produk yang dihasilkan didapatkan nilai baik untuk diteruskan pada tahapa uji coba. Hasil uji coba yang dilakukan secara keseluruan dapat disimpulkan bahwa bahan ajar modul elektronik interaktif memiliki tingkat kelayakan yang baik sekali dan efektif untuk diterapkan pada mata kuliah Inovasi Pendidikan, program studi Teknologi Pendidikan Universitas Baturaja.

\section{E. REFERENSI}

Arikunro, S. 2010. Prosedur Penelitian : Suatu Pendekatan Praktik. Jakarta : Rineka Cipta

Darmawan, D. 2012. Inovasi Pendidikan: Pendekatan Praktik Teknologi Multimedia dan Pembelajaran Online. Bandung: PT Remaja Rosdakarya.

Daryanto. 2013. Menyusun Modul; Bahan Ajar untuk persiapan Guru dalam Mengajar. Yogyakarta: Gava Media. 
Departemen Pendidikan Nasional. 2008. Penulisan Modul. Jakarta: Departemen Pendidikan Nasional.

Hamdani. 2011. Strategi Belajara Mengajar. Bandung: Pustaka Setia.

Lim, J., Yunos, J. M., \& Spahat, G. (2005). Development and evaluation of e-module for pneumatics technology. Konvensyen Teknologi Pendidikan Ke-18, 2(3), 322 $327 . \quad$ Retrieved http://eprints.uthm.edu.my/2804/

Makki, B.(2012). The Impact of Integration of Instructional Systems Technology into Research and Educational Technology. Creative Education, 03(02), 275-280. https://doi.org/10.4236/ce.2012.3203

Panen, paulina \& Purwanto. 2001. Penulisan Bahan Ajar. Jakarta: PAU-PPAI, Universitas Terbuka.

Prastowo, Andi. 2011. Panduan Kreatif Membuat Bahan Ajar Inovatif; Menciptakan Metode Pembelajaran yang Menarik dan Menyenangkan. Jogjakarta: DIVA Pers.

Prawiradilaga, Dewi Salma. 2009. Prinsip Desain Pembelajaran. Jakarta: Kencana.

Sudijono. 2011. Pengantar Statistik Pendidikan. Jakarta : Raja Grafindo Persada.

Sugiyono. 2009. Penelitian Kualitatif, Kuantitatif dan R\&D. Bandung: Alpabeta

Sugiyono. 2010. Penelitian Kualitatif, Kuantitatif dan R\&D. Bandung: Alpabeta

Suprijanto. 2008. Pendidikan Orang Dewasa; dari Teori Hingga Aplikasi. Jakarta: Bumi Aksara.

Tessmer. Martin. 1998. Planning and Conducting Formatif Evaluations. London: Kogan Page 